\title{
APLIKASI SISTEM PENGAMBILAN KEPUTUSAN PEMILIHAN SISWA BERPRESTASI
}

\author{
Arief Setya Budi ${ }^{1}$ \\ Program Studi Sistem Informasi \\ STMIK Nusa Mandiri Jakarta \\ e-mail : ariefsetya334@gmail.com
}

\author{
Ade Fitria Lestari ${ }^{2}$ \\ Program Studi Komputerisasi Akuntansi \\ AMIK BSI Jakarta \\ e-mail : ade.afr@bsi.ac.id
}

\begin{abstract}
Abstrak - Pemilihan siswa berprestasi di Sekolah Menengah Kejuruan (SMK) Yapia Parung yang dilakukan setiap semester masih dilakukan secara konvensional seperti pihak sekolah memerlukan waktu yang cukup lama pada saat proses pemilihan siswa berprestasi karena melakukan pencatatan data siswa yang cukup banyak, selain itu masih kurang relevan dalam pemilihan siswa berprestasi dikarenakan belum menggunakan metode perhitungan yang tepat. Pembuatan laporan hasil pemilihan siswa berprestasi masih memerlukan waktu yang cukup lama di karenakan sistem perekapan laporan masih dilakukan secara manual, dan belum adanya sistem informasi pendukung keputusan untuk menghasilkan pemilihan siswa berprestasi secara objektif dan relevan. Penelitian ini bertujuan merancang dan membangun sistem pendukung keputusan untuk pemilihan siswa berprestasi berbasis web di SMK Yapia Parung dengan metode Technique for Order Preferences by Similarity to an Ideal Solution (TOPSISri nilai ekstrakulikuler.
\end{abstract}

Key Word: Selection of Outstanding Students, Decision Support System, TOPSIS.

\section{PENDAHULUAN}

Sekolah Menengah Kejuruan (SMK) Yapia Parung merupakan salah satu SMK Swasta yang terletak di wilayah Parung. Demi menunjang dan meningkatkan prestasi siswa, SMK Yapia Parung menyediakan berbagai fasilitas, mulai dari bimbingan, kegiatan organisasi, ekstrakurikuler, hingga keikutsertaan lomba. Sekolah pun akan memberi reward bagi siswa yang dianggap berprestasi. Pemilihan siswa berprestasi di SMK Yapia Parung selalu dilaksanakan setiap semester. Pemilihan siswa berprestasi juga juga diperlakukan pihak sekolah untuk kepentingan eksternal, seperti pemberian data siswa berprestasi kepada Dinas Pemerintahan Kota maupun Provinsi. Kepala Sekolah SMK Yapia Parung mendapat kewenangan untuk memilih siswa berprestasi. Namun dengan sistem yang masih manual pihak sekolah memerlukan waktu yang cukup lama pada saat proses pemilihan siswa berprestasi. Karena melakukan pencatatan data siswa yang cukup banyak. Selain itu masih kurang relevan dalam pemilihan siswa berprestasi dikarenakan belum
Kata Kunci: Pemilihan Siswa Berprestasi, Sistem Pendukung Keputusan, TOPSIS.

\begin{abstract}
The selection of outstanding students in Yapia Parung Vocational School (SMK) conducted every semester is still done conventionally as the school requires a considerable amount of time during the process of selecting high achieving students because there are quite a lot of student data recording, besides that it is still less relevant in the selection outstanding students because they have not used the right calculation method. Making a report on the results of the selection of high achieving students still requires a considerable amount of time because the report recording system is still done manually, and there is no decision support information system to produce an objective and relevant selection of achieving students. This study aims to design and build a decision support system for the selection of webbased achievement students at Yapia Parung Vocational School with the Technique for Order Preferences by Similarity to Ideal Solution (TOPSIS) method.
\end{abstract}

menggunakan metode perhitungan yang tepat. Pembuatan laporan hasil pemilihan siswa berprestasi masih memerlukan waktu yang cukup lama di karenakan masih menggunakan sistem perekapan laporan secara manual. Pihak sekolah Telah berencana untuk beralih ke sistem pemilihan siswa berprestasi yang mengacu pada Paduan Penilaian Prestasi Siswa yang akan dibuat dan ditunjang dengan penilaian akademik siswa, dengan harapan agar hasil yang diperoleh lebih objektif. Namun sistem baru tersebut belum di implementasikan oleh pihak sekolah karena belum adanya sistem informasi yang mendukung pemilihan siswa berprestasi pada SMK Yapia Parung.

Berdasarkan permasalahan tersebut, perlu dibangun sebuah sistem informasi pendukung keputusan untuk mendukung proses pemilihan siswa berprestasi berbasis web di SMK Yapia Parung. Sistem ini bertujuan untuk memperoleh hasil perankingan secara cepat dan objektif menggunakan metode TOPSIS.

\section{METODE PENELITIAN}


Dalam penelitian ini, penulis melakukan beberapa metode penelitian yaitu:

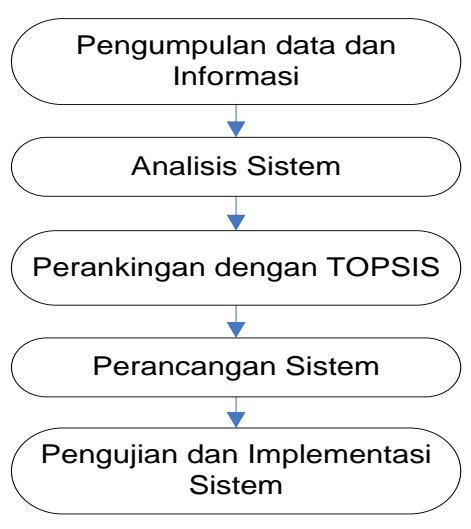

Gambar 1. Tahapan Penelitian

Sumber : Hasil Penelitian (2018)

\section{Metode Pengumpulan Data}

Penulis melakukan teknik pengumpulan data dengan beberapa tahap yaitu : 1) melakukan observasi pada bagian Tata usaha bagian umum guna memperoleh data siswa berprestasi, data tersebut diolah dan disajikan dalam sistem informasi berbasis web, 2) Wawancara kepada Tata usaha bagian umum guna mengetahui informasi pemilihan prestasi siswa, 3) Pengumpulan informasi dengan cara mencari referensi yang berhubungan dengan penelitian diambil dari literatur.

\section{Analisis Sistem}

Dalam menganalisis sistem, penulis menggunakan metode waterfall dalam mengembangkan perangkat lunak, dengan menganalisa kebutuhan software, merancang sistem, dalam merealisasikan desain kedalam bahasa pemrograman PHP, sebelum diimplementasikan dilakukan pengujian terlebih dahulu.

\section{Metode TOPSIS}

Sistem Penunjang Keputusan (SPK) atau dikenal juga dengan Decision Support System (DSS) adalah salah satu subsistem dari Sistem Informasi Berbasis Komputer atau Computer Based System Information (CBIS) yang dapat menyediakan informasi yang berguna bagi proses pengambilan keputusan ketika menghadapi sebuah masalah semi terstruktur yang spesifik. (Amalia \& Evicienna, 2013). Salah satu Sistem Penunjang Keputusan adalah metode TOPSIS yang merupakan salah satu pengambilan keputusan multikriteria, yang menggunakan prinsip bahwa alternatif terpilih harus mempunyai jarak terdekat dari solusi ideal positif dan terjauh dari solusi ideal negatif dari sudut pandang geometris dengan menggunakan jarak Euclidean untuk menentukan kedekatan relatif dari suatu alternatif dengan solusi optimal. (Wijaya, Wowor \& Tulenan, 2015). TOPSIS didasarkan pada konsep penghitungan rating kinerja setiap kriteria yang ternormalisasi (Mardiana,2018)

Dalam penelitian ini penentuan siswa berprestasi diambil perjurusan kelas X, XI, dan XII dengan TOPSIS untuk dilakukan perankingan.

\section{Perancangan Sistem}

Tahapan selanjutnya adalah merancang aplikasi sistem pemilihan siswa berprestasi berdasarkan kebutuhan dan analisa sistem yang sudah dilakukan dan diolah. Rancangan sistem menggunakan diagram UML diantaranya use case diagram, activity diagram, component dan deployment diagram dan untuk rancangan databasenya dengan diagram ERD (Entity Relationship Diagram).

\section{Pengujian dan Implementasi}

Sebelum Implementasi harus dilakukan pengujian terlebih dahulu untuk menguji input dan output hasil program apakah sudah sesuai yang diharapkan, pengujian dilakukan dengan black box testing.

\section{HASIL DAN PEMBAHASAN}

Penentuan siswa berprestasi pada SMK YAPIA PARUNG akan dimulai perjurusan untuk kelas $\mathrm{X}$ kelas XI dan kelas XII, maka dari itu diambil tiga sampel siswa perkelas dengan nilai tertinggi berdasarkan jurusan untuk penerapan dan perangkingan menggunakan metode Technique for Others Preference by Similarity to Ideal Solution (TOPSIS) dalam penentuan siswa berprestasi. Tahapannya sebagai berikut :

\section{Kriteria Penilaian}

Ada 5 kriteria yang dijadikan acuan dalam pengambilan keputusan yaitu Nilai rata-rata raport, nilai absen,nilai sikap, nilai prestasi dan nilai ekstrakurikuler.

Tabel 1.

Kriteria Penilaian

\begin{tabular}{|l|l|l|l|l|l|}
\hline $\begin{array}{l}\text { Alternati } \\
\mathrm{f}\end{array}$ & $\begin{array}{l}\text { Nilai } \\
\text { Rata- } \\
\text { rata } \\
\text { Rapor } \\
\mathrm{t}\end{array}$ & $\begin{array}{l}\text { Nilai } \\
\text { Abse } \\
\mathrm{n}\end{array}$ & $\begin{array}{l}\text { Nilai } \\
\text { Sika } \\
\mathrm{p}\end{array}$ & $\begin{array}{l}\text { Nilai } \\
\text { Prestas } \\
\mathrm{i}\end{array}$ & $\begin{array}{l}\text { Nilai } \\
\text { Ekstrakurikul } \\
\text { er }\end{array}$ \\
\hline S1 & 86 & $\mathrm{~A}$ & $\mathrm{~A}$ & 1 & 3 \\
\hline S2 & 86 & $\mathrm{~B}$ & $\mathrm{~B}$ & 1 & 2 \\
\hline S3 & 85 & $\mathrm{~B}$ & $\mathrm{~B}$ & 1 & 1 \\
\hline S4 & 88 & $\mathrm{~B}$ & $\mathrm{~B}$ & 1 & 1 \\
\hline S5 & 85 & $\mathrm{~B}$ & $\mathrm{~A}$ & 1 & 2 \\
\hline S6 & 85 & $\mathrm{~B}$ & $\mathrm{~A}$ & 1 & 2 \\
\hline S7 & 91 & $\mathrm{~A}$ & $\mathrm{~A}$ & 1 & 2 \\
\hline S8 & 89 & $\mathrm{~A}$ & $\mathrm{~B}$ & 1 & 1 \\
\hline S9 & 88 & A & A & 1 & 2 \\
\hline S10 & 88.8 & B & B & 1 & 1 \\
\hline
\end{tabular}




\begin{tabular}{|c|c|c|c|c|c|}
\hline S11 & 88.3 & B & B & 1 & 1 \\
\hline S12 & 84.1 & B & B & 1 & 1 \\
\hline S13 & 88 & $\mathrm{~A}$ & B & 1 & 3 \\
\hline S14 & 87 & B & A & 1 & 2 \\
\hline S15 & 84 & B & $\mathrm{C}$ & 1 & 2 \\
\hline S16 & 88 & A & A & 1 & 3 \\
\hline S17 & 87 & B & B & 2 & 2 \\
\hline S18 & 86 & B & B & 1 & 2 \\
\hline S19 & 89.1 & B & B & 1 & 1 \\
\hline $\mathbf{S 2 0}$ & 86.8 & A & $\mathrm{C}$ & 1 & 1 \\
\hline S21 & 86.3 & B & B & 1 & 1 \\
\hline S22 & 87 & B & B & 1 & 1 \\
\hline S23 & 87 & B & A & 1 & 2 \\
\hline S24 & 86 & B & $\mathrm{A}$ & 1 & 4 \\
\hline S25 & 93 & $\mathrm{~B}$ & $\mathrm{~A}$ & 3 & 3 \\
\hline S26 & 91 & B & B & 3 & 1 \\
\hline S27 & 91 & B & A & 2 & 4 \\
\hline S28 & 93.6 & A & $\mathrm{A}$ & 1 & 2 \\
\hline S29 & 92.7 & B & $\mathrm{A}$ & 1 & 2 \\
\hline S30 & 90.6 & A & B & 1 & 1 \\
\hline S31 & 88 & B & A & 1 & 2 \\
\hline S32 & 87 & B & $\mathrm{A}$ & 1 & 2 \\
\hline S33 & 87 & A & $\mathrm{B}$ & 1 & 2 \\
\hline S34 & 84 & B & B & 1 & 1 \\
\hline $\mathbf{S 3 5}$ & 84 & B & $\mathrm{A}$ & 1 & 3 \\
\hline S36 & 84 & B & $\mathrm{B}$ & 1 & 1 \\
\hline S37 & 87 & A & $\mathrm{A}$ & 1 & 2 \\
\hline S38 & 86 & $\mathrm{~A}$ & $\mathrm{~B}$ & 1 & 1 \\
\hline S39 & 86 & B & B & 1 & 1 \\
\hline S40 & 86 & B & $\mathrm{A}$ & 1 & 2 \\
\hline S41 & 83 & B & B & 1 & 1 \\
\hline S42 & 82 & B & B & 1 & 1 \\
\hline S43 & 89 & A & B & 1 & 1 \\
\hline S44 & 88 & B & B & 1 & 1 \\
\hline S45 & 88 & B & $\mathrm{A}$ & 1 & 1 \\
\hline S46 & 88 & $\mathrm{~A}$ & $\mathrm{~B}$ & 1 & 1 \\
\hline S47 & 87 & B & B & 1 & 1 \\
\hline S48 & 87 & A & B & 1 & 1 \\
\hline S49 & 89 & A & B & 1 & 1 \\
\hline S50 & 87 & A & B & 1 & 1 \\
\hline S51 & 86 & B & B & 1 & 1 \\
\hline S52 & 88 & B & A & 1 & 1 \\
\hline S53 & 88 & B & B & 1 & 1 \\
\hline S54 & 87 & B & A & 1 & 2 \\
\hline S55 & 93.2 & A & B & 1 & 1 \\
\hline S56 & 90.6 & $\mathrm{~A}$ & $\mathrm{~A}$ & 1 & 2 \\
\hline S57 & 89.8 & B & $\mathrm{B}$ & 1 & 1 \\
\hline S58 & 89.9 & B & $\mathrm{C}$ & 1 & 1 \\
\hline S59 & 89.2 & B & B & 1 & 2 \\
\hline S60 & 89.1 & B & $\mathrm{B}$ & 1 & 1 \\
\hline S61 & 87.9 & $\mathrm{~A}$ & $\mathrm{~A}$ & 1 & 1 \\
\hline S62 & 87.8 & A & $\mathrm{B}$ & 1 & 1 \\
\hline S63 & 87.2 & A & $\mathrm{C}$ & 1 & 1 \\
\hline
\end{tabular}

Sumber: Hasil Penelitian (2018)

\section{Bobot Penilaian}

Menentukan nilai bobot dilakukan dengan memilih nilai ranking kecocokan antara alternatif dan kriteria dengan interval dari 1 sampai 5, dengan ketentuan sebagai berikut :

Tabel 2.

Tabel kriteria dan bobot penilaian

\begin{tabular}{|l|l|l|l|}
\hline No & Atribut & Nilai & Nilai Kecocokan \\
\hline \multirow{3}{*}{1} & Nilai rata-rata raport & $0-39$ & 1 \\
\cline { 3 - 4 } & & $40-59$ & 2 \\
\cline { 3 - 4 } & & $60-74$ & 3 \\
\hline
\end{tabular}

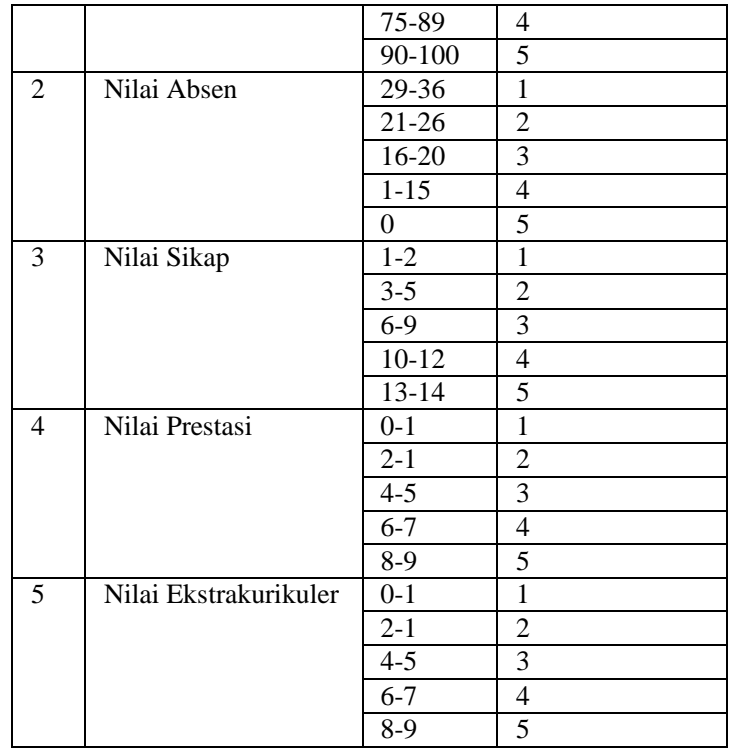

Berikut data matriks keputusan ternormalisasi:

Tabel 3. Tabel matriks keputusan ternormalisasi

\begin{tabular}{|l|l|l|l|l|l|}
\hline $\begin{array}{l}\text { Alte } \\
\text { rnati } \\
\text { ve }\end{array}$ & C1 & C2 & C3 & C4 & C5 \\
\hline A1 & 0.1188 & 0.144 & 0.1451 & 0.1085 & 0.2159 \\
\hline A2 & 0.1188 & 0.1152 & 0.1161 & 0.1085 & 0.144 \\
\hline A3 & 0.1188 & 0.1152 & 0.1161 & 0.1085 & 0.072 \\
\hline A4 & 0.1188 & 0.1152 & 0.1161 & 0.1085 & 0.072 \\
\hline A5 & 0.1188 & 0.1152 & 0.1451 & 0.1085 & 0.144 \\
\hline A6 & 0.1188 & 0.1152 & 0.1451 & 0.1085 & 0.144 \\
\hline A7 & 0.1485 & 0.144 & 0.1451 & 0.1085 & 0.144 \\
\hline A8 & 0.1188 & 0.144 & 0.1161 & 0.1085 & 0.072 \\
\hline A9 & 0.1188 & 0.144 & 0.1451 & 0.1085 & 0.144 \\
\hline A10 & 0.1188 & 0.1152 & 0.1161 & 0.1085 & 0.072 \\
\hline A11 & 0.1188 & 0.1152 & 0.1161 & 0.1085 & 0.072 \\
\hline A12 & 0.1188 & 0.1152 & 0.1161 & 0.1085 & 0.072 \\
\hline A13 & 0.1188 & 0.144 & 0.1161 & 0.1085 & 0.2159 \\
\hline A14 & 0.1188 & 0.1152 & 0.1451 & 0.1085 & 0.144 \\
\hline A15 & 0.1188 & 0.1152 & 0.0871 & 0.1085 & 0.144 \\
\hline A16 & 0.1188 & 0.144 & 0.1451 & 0.1085 & 0.2159 \\
\hline A17 & 0.1188 & 0.1152 & 0.1161 & 0.2169 & 0.144 \\
\hline A18 & 0.1188 & 0.1152 & 0.1161 & 0.1085 & 0.144 \\
\hline A19 & 0.1485 & 0.1152 & 0.1161 & 0.1085 & 0.072 \\
\hline A20 & 0.1188 & 0.144 & 0.0871 & 0.1085 & 0.072 \\
\hline A21 & 0.1188 & 0.1152 & 0.1161 & 0.1085 & 0.072 \\
\hline A22 & 0.1188 & 0.1152 & 0.1161 & 0.1085 & 0.072 \\
\hline A23 & 0.1188 & 0.1152 & 0.1451 & 0.1085 & 0.144 \\
\hline A24 & 0.1188 & 0.1152 & 0.1451 & 0.1085 & 0.2879 \\
\hline A25 & 0.1485 & 0.1152 & 0.1451 & 0.3254 & 0.2159 \\
\hline A26 & 0.1485 & 0.1152 & 0.1161 & 0.3254 & 0.072 \\
\hline A27 & 0.1485 & 0.1152 & 0.1451 & 0.2169 & 0.2879 \\
\hline A28 & 0.1485 & 0.144 & 0.1451 & 0.1085 & 0.144 \\
\hline A29 & 0.1485 & 0.1152 & 0.1451 & 0.1085 & 0.144 \\
\hline A30 & 0.1485 & 0.144 & 0.1161 & 0.1085 & 0.072 \\
\hline A31 & 0.1188 & 0.1152 & 0.1451 & 0.1085 & 0.144 \\
\hline A32 & 0.1188 & 0.1152 & 0.1451 & 0.1085 & 0.144 \\
\hline A33 & 0.1188 & 0.144 & 0.1161 & 0.1085 & 0.144 \\
\hline A34 & 0.1188 & 0.1152 & 0.1161 & 0.1085 & 0.072 \\
\hline A35 & 0.1188 & 0.1152 & 0.1451 & 0.1085 & 0.2159 \\
\hline A36 & 0.1188 & 0.1152 & 0.1161 & 0.1085 & 0.072 \\
\hline A37 & 0.1188 & 0.144 & 0.1451 & 0.1085 & 0.144 \\
\hline A38 & 0.1188 & 0.144 & 0.1161 & 0.1085 & 0.072 \\
\hline A39 & 0.1188 & 0.1152 & 0.1161 & 0.1085 & 0.072 \\
\hline
\end{tabular}




\begin{tabular}{|l|l|l|l|l|l|}
\hline $\mathbf{A 4 0}$ & 0.1188 & 0.1152 & 0.1451 & 0.1085 & 0.144 \\
\hline $\mathbf{A 4 1}$ & 0.1188 & 0.1152 & 0.1161 & 0.1085 & 0.072 \\
\hline $\mathbf{A 4 2}$ & 0.1188 & 0.1152 & 0.1161 & 0.1085 & 0.072 \\
\hline $\mathbf{A 4 3}$ & 0.1188 & 0.144 & 0.1161 & 0.1085 & 0.072 \\
\hline $\mathbf{A 4 4}$ & 0.1188 & 0.1152 & 0.1161 & 0.1085 & 0.072 \\
\hline $\mathbf{A 4 5}$ & 0.1188 & 0.1152 & 0.1451 & 0.1085 & 0.072 \\
\hline $\mathbf{A 4 6}$ & 0.1188 & 0.144 & 0.1161 & 0.1085 & 0.072 \\
\hline $\mathbf{A 4 7}$ & 0.1188 & 0.1152 & 0.1161 & 0.1085 & 0.072 \\
\hline $\mathbf{A 4 8}$ & 0.1188 & 0.144 & 0.1161 & 0.1085 & 0.072 \\
\hline $\mathbf{A 4 9}$ & 0.1188 & 0.144 & 0.1161 & 0.1085 & 0.072 \\
\hline $\mathbf{A 5 0}$ & 0.1188 & 0.144 & 0.1161 & 0.1085 & 0.072 \\
\hline $\mathbf{A 5 1}$ & 0.1188 & 0.1152 & 0.1161 & 0.1085 & 0.072 \\
\hline $\mathbf{A 5 2}$ & 0.1188 & 0.1152 & 0.1451 & 0.1085 & 0.072 \\
\hline $\mathbf{A 5 3}$ & 0.1188 & 0.1152 & 0.1161 & 0.1085 & 0.072 \\
\hline $\mathbf{A 5 4}$ & 0.1188 & 0.1152 & 0.1451 & 0.1085 & 0.144 \\
\hline $\mathbf{A 5 5}$ & 0.1485 & 0.144 & 0.1161 & 0.1085 & 0.072 \\
\hline $\mathbf{A 5 6}$ & 0.1485 & 0.144 & 0.1451 & 0.1085 & 0.144 \\
\hline $\mathbf{A 5 7}$ & 0.1485 & 0.1152 & 0.1161 & 0.1085 & 0.072 \\
\hline $\mathbf{A 5 8}$ & 0.1485 & 0.1152 & 0.0871 & 0.1085 & 0.072 \\
\hline $\mathbf{A 5 9}$ & 0.1485 & 0.1152 & 0.1161 & 0.1085 & 0.144 \\
\hline $\mathbf{A 6 0}$ & 0.1485 & 0.1152 & 0.1161 & 0.1085 & 0.072 \\
\hline $\mathbf{A 6 1}$ & 0.1188 & 0.144 & 0.1451 & 0.1085 & 0.072 \\
\hline $\mathbf{A 6 2}$ & 0.1188 & 0.144 & 0.1161 & 0.1085 & 0.072 \\
\hline $\mathbf{A 6 3}$ & 0.1188 & 0.144 & 0.0871 & 0.1085 & 0.072 \\
\hline Sum & $\mathbf{H}$ & $\mathrm{Ha}$ \\
\hline
\end{tabular}

Sumber: Hasil Penelitian (2018)

Berikut data matriks ternormalisasi dengan bobot:

Tabel 5.

Tabel matriks ternormalisasi terbobot

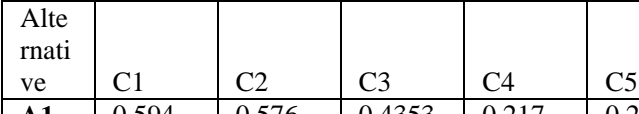

\begin{tabular}{|l|l|l|l|l|l|}
\hline $\mathbf{A 1}$ & 0.594 & 0.576 & 0.4353 & 0.217 & 0.2159 \\
\hline $\mathbf{A 2}$ & 0.594 & 0.4608 & 0.3483 & 0.217 & 0.144 \\
\hline
\end{tabular}

\begin{tabular}{|l|l|l|l|l|l|}
\hline $\mathbf{A 2}$ & 0.594 & 0.4608 & 0.3483 & 0.217 & 0.144 \\
\hline $\mathbf{A 3}$ & 0.594 & 0.4608 & 0.3483 & 0.217 & 0.072 \\
\hline
\end{tabular}

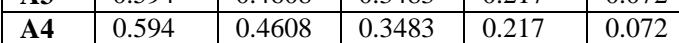

\begin{tabular}{l|l|l|l|l|l} 
A5 & 0.594 & 0.4608 & 0.4353 & 0.217 & 0.144 \\
\hline
\end{tabular}

\begin{tabular}{|l|l|l|l|l|l|}
\hline $\mathbf{A 6}$ & 0.594 & 0.4608 & 0.4353 & 0.217 & 0.144 \\
\hline
\end{tabular}

\begin{tabular}{|l|l|l|l|l|l|}
\hline $\mathbf{A 7}$ & 0.7425 & 0.576 & 0.4353 & 0.217 & 0.144 \\
\hline $\mathbf{A 8}$ & 0.594 & 0.576 & 0.3483 & 0.217 & 0.072 \\
\hline
\end{tabular}

\begin{tabular}{l|l|l|l|l|l}
$\mathbf{A 8}$ & 0.594 & 0.576 & 0.3483 & 0.217 & 0.072
\end{tabular}

\begin{tabular}{l|l|l|l|l|l} 
A9 & 0.594 & 0.576 & 0.4353 & 0.217 & 0.144 \\
\hline
\end{tabular}

\begin{tabular}{l|l|l|l|l|l}
$\mathbf{A 1 0}$ & 0.594 & 0.4608 & 0.3483 & 0.217 & 0.072
\end{tabular}

\begin{tabular}{l|l|l|l|l|l}
$\mathbf{A 1 1}$ & 0.594 & 0.4608 & 0.3483 & 0.217 & 0.072 \\
\hline $\mathbf{A 1 2}$ & 0.594 & 0.4608 & 0.3483 & 0.217 & 0.072
\end{tabular}

\begin{tabular}{|l|l|l|l|l|l|}
\hline $\mathbf{A 1 2}$ & 0.594 & 0.4608 & 0.3483 & 0.217 & 0.072 \\
\hline $\mathbf{A 1 3}$ & 0.594 & 0.576 & 0.3483 & 0.217 & 0.2159 \\
\hline $\mathbf{A 1 4}$ & 0.594 & 0.4608 & 0.4353 & 0.217 & 0.144 \\
\hline
\end{tabular}

\begin{tabular}{l|l|l|l|l|l}
$\mathbf{A 1 4}$ & 0.594 & 0.4608 & 0.4353 & 0.217 & 0.144
\end{tabular}

\begin{tabular}{l|l|l|l|l|l}
$\mathbf{A 1 5}$ & 0.594 & 0.4608 & 0.2613 & 0.217 & 0.144 \\
\hline
\end{tabular}

\begin{tabular}{|l|l|l|l|l|l|}
\hline A16 & 0.594 & 0.576 & 0.4353 & 0.217 & 0.2159 \\
\hline
\end{tabular}

\begin{tabular}{l|l|l|l|l|l|}
\hline $\mathbf{A 1 7}$ & 0.594 & 0.4608 & 0.3483 & 0.4338 & 0.144 \\
\hline $\mathbf{A 1 8}$ & 0.594 & 0.4608 & 0.3483 & 0.217 & 0.144
\end{tabular}

\begin{tabular}{|l|l|l|l|l|l}
\hline $\mathbf{A 1 8}$ & 0.594 & 0.4608 & 0.3483 & 0.217 & 0.144 \\
\hline $\mathbf{A 1 9}$ & 0.7425 & 0.4608 & 0.3483 & 0.217 & 0.072 \\
\hline
\end{tabular}

\begin{tabular}{|l|l|l|l|l|l|}
\hline $\mathbf{A 1 9}$ & 0.7425 & 0.4608 & 0.3483 & 0.217 & 0.072 \\
\hline $\mathbf{A 2 0}$ & 0.594 & 0.576 & 0.2613 & 0.217 & 0.072
\end{tabular}

\begin{tabular}{|l|l|l|l|l|l|}
\hline $\mathbf{A 2 0}$ & 0.594 & 0.576 & 0.2613 & 0.217 & 0.072 \\
\hline
\end{tabular}

\begin{tabular}{|l|l|l|l|l|l|}
\hline $\mathbf{A 2 1}$ & 0.594 & 0.4608 & 0.3483 & 0.217 & 0.072 \\
\hline $\mathbf{A 2 2}$ & 0.594 & 0.4608 & 0.3483 & 0.217 & 0.072 \\
\hline
\end{tabular}

\begin{tabular}{|l|l|l|l|l|l}
\hline $\mathbf{A 2 3}$ & 0.594 & 0.4608 & 0.4353 & 0.217 & 0.144 \\
\hline
\end{tabular}

\begin{tabular}{|l|l|l|l|l|l|}
\hline $\mathbf{A 2 4}$ & 0.594 & 0.4608 & 0.4353 & 0.217 & 0.2879 \\
\hline $\mathbf{A 2 5}$ & 0.7425 & 0.4608 & 0.4353 & 0.6508 & 0.2159 \\
\hline
\end{tabular}

\begin{tabular}{l|l|l|l|l|l}
$\mathbf{A 2 5}$ & 0.7425 & 0.4608 & 0.4353 & 0.6508 & 0.2159 \\
\hline
\end{tabular}

\begin{tabular}{l|l|l|l|l|l} 
A26 & 0.7425 & 0.4608 & 0.3483 & 0.6508 & 0.072
\end{tabular}

\begin{tabular}{l|l|l|l|l|l|}
$\mathbf{A 2 7}$ & 0.7425 & 0.4608 & 0.4353 & 0.4338 & 0.2879 \\
\hline
\end{tabular}

\begin{tabular}{|l|l|l|l|l|l}
\hline $\mathbf{A 2 8}$ & 0.7425 & 0.576 & 0.4353 & 0.217 & 0.144 \\
\hline
\end{tabular}

\begin{tabular}{l|l|l|l|l|l}
$\mathbf{A 2 9}$ & 0.7425 & 0.4608 & 0.4353 & 0.217 & 0.144
\end{tabular}

\begin{tabular}{l|l|l|l|l|l}
\hline A30 & 0.7425 & 0.576 & 0.3483 & 0.217 & 0.072 \\
\hline
\end{tabular}

\begin{tabular}{l|l|l|l|l|l}
$\mathbf{A 3 1}$ & 0.594 & 0.4608 & 0.4353 & 0.217 & 0.144
\end{tabular}

\begin{tabular}{l|l|l|l|l|l} 
A32 & 0.594 & 0.4608 & 0.4353 & 0.217 & 0.144 \\
\hline
\end{tabular}

\begin{tabular}{l|l|l|l|l|l}
$\mathbf{A 3 3}$ & 0.594 & 0.576 & 0.3483 & 0.217 & 0.144
\end{tabular}

\begin{tabular}{l|l|l|l|l|l}
\hline A34 & 0.594 & 0.4608 & 0.3483 & 0.217 & 0.072 \\
\hline A35 & 0.594 & 0.4608 & 0.4353 & 0.217 & 0.2159 \\
\hline
\end{tabular}

\begin{tabular}{l|l|l|l|l|l|} 
A335 & 0.594 & 0.4608 & 0.4353 & 0.217 & 0.2159 \\
\hline
\end{tabular}

\begin{tabular}{l|l|l|l|l|l} 
A36 & 0.594 & 0.4608 & 0.3483 & 0.217 & 0.072 \\
\hline
\end{tabular}

\begin{tabular}{|c|c|c|c|c|c|}
\hline A37 & 0.594 & 0.576 & 0.4353 & 0.217 & 0.144 \\
\hline A38 & 0.594 & 0.576 & 0.3483 & 0.217 & 0.072 \\
\hline A39 & 0.594 & 0.4608 & 0.3483 & 0.217 & 0.072 \\
\hline A40 & 0.594 & 0.4608 & 0.4353 & 0.217 & 0.144 \\
\hline A41 & 0.594 & 0.4608 & 0.3483 & 0.217 & 0.072 \\
\hline A42 & 0.594 & 0.4608 & 0.3483 & 0.217 & 0.072 \\
\hline A43 & 0.594 & 0.576 & 0.3483 & 0.217 & 0.072 \\
\hline A44 & 0.594 & 0.4608 & 0.3483 & 0.217 & 0.072 \\
\hline A45 & 0.594 & 0.4608 & 0.4353 & 0.217 & 0.072 \\
\hline A46 & 0.594 & 0.576 & 0.3483 & 0.217 & 0.072 \\
\hline A47 & 0.594 & 0.4608 & 0.3483 & 0.217 & 0.072 \\
\hline A48 & 0.594 & 0.576 & 0.3483 & 0.217 & 0.072 \\
\hline A49 & 0.594 & 0.576 & 0.3483 & 0.217 & 0.072 \\
\hline A50 & 0.594 & 0.576 & 0.3483 & 0.217 & 0.072 \\
\hline A51 & 0.594 & 0.4608 & 0.3483 & 0.217 & 0.072 \\
\hline A52 & 0.594 & 0.4608 & 0.4353 & 0.217 & 0.072 \\
\hline $\mathbf{A 5 3}$ & 0.594 & 0.4608 & 0.3483 & 0.217 & 0.072 \\
\hline A54 & 0.594 & 0.4608 & 0.4353 & 0.217 & 0.144 \\
\hline A55 & 0.7425 & 0.576 & 0.3483 & 0.217 & 0.072 \\
\hline A56 & 0.7425 & 0.576 & 0.4353 & 0.217 & 0.144 \\
\hline A57 & 0.7425 & 0.4608 & 0.3483 & 0.217 & 0.072 \\
\hline A58 & 0.7425 & 0.4608 & 0.2613 & 0.217 & 0.072 \\
\hline A59 & 0.7425 & 0.4608 & 0.3483 & 0.217 & 0.144 \\
\hline A60 & 0.7425 & 0.4608 & 0.3483 & 0.217 & 0.072 \\
\hline A61 & 0.594 & 0.576 & 0.4353 & 0.217 & 0.072 \\
\hline A62 & 0.594 & 0.576 & 0.3483 & 0.217 & 0.072 \\
\hline A63 & 0.594 & 0.576 & 0.2613 & 0.217 & 0.072 \\
\hline
\end{tabular}

Sumber: Hasil Penelitian (2018)

Berikut data solusi ideal positif dan negatif :

$\begin{array}{ll}\mathrm{y} 1+=0.7425 & \mathrm{y} 1-=0.594 \\ \mathrm{y} 2+=0.576 & \mathrm{y} 2-=0.4608 \\ \mathrm{y} 3+=0.4353 & \mathrm{y} 3-=0.2613 \\ \mathrm{y} 4+=0.6508 & \mathrm{y} 4-=0.217 \\ \mathrm{y} 5+=0.2879 & \mathrm{y} 5-=0.072\end{array}$

Sumber: Hasil Penelitian (2018)

Berikut data matriks ternormalisasi dengan bobot:

Tabel 6.

Tabel Solusi ideal positif dan negatif

\begin{tabular}{|l|l|l|}
\hline Y & Max & Min \\
\hline Y1 & 0.46413 & 0.25348 \\
\hline Y2 & 0.50178 & 0.11293 \\
\hline Y3 & 0.52696 & 0.087 \\
\hline Y4 & 0.52696 & 0.087 \\
\hline Y5 & 0.49418 & 0.18831 \\
\hline Y6 & 0.49418 & 0.18831 \\
\hline Y7 & 0.45704 & 0.26605 \\
\hline Y8 & 0.51421 & 0.14436 \\
\hline Y9 & 0.48056 & 0.22075 \\
\hline Y10 & 0.52696 & 0.087 \\
\hline Y11 & 0.52696 & 0.087 \\
\hline Y12 & 0.52696 & 0.087 \\
\hline Y13 & 0.47222 & 0.20383 \\
\hline Y14 & 0.49418 & 0.18831 \\
\hline Y15 & 0.52392 & 0.072 \\
\hline Y16 & 0.46413 & 0.25348 \\
\hline Y17 & 0.3327 & 0.24445 \\
\hline Y18 & 0.50178 & 0.11293 \\
\hline Y19 & 0.5056 & 0.17211 \\
\hline Y20 & 0.53584 & 0.1152 \\
\hline Y21 & 0.52696 & 0.087 \\
\hline Y22 & 0.52696 & 0.087 \\
\hline Y23 & 0.49418 & 0.18831 \\
\hline Y24 & 0.47276 & 0.27729 \\
\hline Y25 & 0.13585 & 0.51109 \\
\hline Y26 & 0.25972 & 0.46669 \\
\hline & & \\
\hline
\end{tabular}




\begin{tabular}{|l|l|l|}
\hline Y27 & 0.24568 & 0.38203 \\
\hline Y28 & 0.45704 & 0.26605 \\
\hline Y29 & 0.47134 & 0.23982 \\
\hline Y30 & 0.49231 & 0.2071 \\
\hline Y31 & 0.49418 & 0.18831 \\
\hline Y32 & 0.49418 & 0.18831 \\
\hline Y33 & 0.48838 & 0.16132 \\
\hline Y34 & 0.52696 & 0.087 \\
\hline Y35 & 0.47822 & 0.22579 \\
\hline Y36 & 0.52696 & 0.087 \\
\hline Y37 & 0.48056 & 0.22075 \\
\hline Y38 & 0.51421 & 0.14436 \\
\hline Y39 & 0.52696 & 0.087 \\
\hline Y40 & 0.49418 & 0.18831 \\
\hline Y41 & 0.52696 & 0.087 \\
\hline Y42 & 0.52696 & 0.087 \\
\hline Y43 & 0.51421 & 0.14436 \\
\hline Y44 & 0.52696 & 0.087 \\
\hline Y45 & 0.51973 & 0.174 \\
\hline Y46 & 0.51421 & 0.14436 \\
\hline Y47 & 0.52696 & 0.087 \\
\hline Y48 & 0.51421 & 0.14436 \\
\hline Y49 & 0.51421 & 0.14436 \\
\hline Y50 & 0.51421 & 0.14436 \\
\hline Y51 & 0.52696 & 0.087 \\
\hline Y52 & 0.51973 & 0.174 \\
\hline Y53 & 0.52696 & 0.087 \\
\hline Y54 & 0.49418 & 0.18831 \\
\hline Y55 & 0.49231 & 0.2071 \\
\hline Y56 & 0.45704 & 0.26605 \\
\hline Y57 & 0.5056 & 0.17211 \\
\hline Y58 & 0.52758 & 0.1485 \\
\hline Y59 & 0.4793 & 0.18656 \\
\hline Y60 & 0.5056 & 0.17211 \\
\hline Y61 & 0.5068 & 0.20868 \\
\hline Y62 & 0.51421 & 0.14436 \\
\hline Y63 & 0.53584 & 0.1152 \\
\hline & \\
\hline & \\
\hline
\end{tabular}

Sumber: Hasil Penelitian (2018)

Berikut nilai preferensi untuk setiap alternatif :

Tabel 7.

Tabel nilai preferensi

\begin{tabular}{|l|l|l|}
\hline Alternatif & NIS & $\mathbf{V}_{\mathbf{i}}$ \\
\hline S1 & 17182316 & 0.3532 \\
\hline S2 & 17182358 & 0.1837 \\
\hline S3 & 17182314 & 0.1417 \\
\hline S4 & 17182308 & 0.1417 \\
\hline S5 & 17182349 & 0.2759 \\
\hline S6 & 17182359 & 0.2759 \\
\hline S7 & 16172003 & 0.3679 \\
\hline S8 & 16172017 & 0.2192 \\
\hline S9 & 16172007 & 0.3148 \\
\hline S10 & 10151745 & 0.1417 \\
\hline S11 & 10151726 & 0.1417 \\
\hline S12 & 10151713 & 0.1417 \\
\hline S13 & 17182452 & 0.3015 \\
\hline S14 & 17182450 & 0.2759 \\
\hline S15 & 17192411 & 0.1208 \\
\hline S16 & 16172082 & 0.3532 \\
\hline S17 & 16172098 & 0.4235 \\
\hline S18 & 16172092 & 0.1837 \\
\hline S19 & 10151851 & 0.254 \\
\hline S20 & 10151846 & 0.177 \\
\hline S21 & 10151834 & 0.1417 \\
\hline S22 & 17182375 & 0.1417 \\
\hline S23 & 17182407 & 0.2759 \\
\hline & & \\
\hline
\end{tabular}

\begin{tabular}{|c|c|c|}
\hline S24 & 17182399 & 0.3697 \\
\hline S25 & 16172065 & 0.79 \\
\hline S26 & 16172062 & 0.6425 \\
\hline S27 & 16172057 & 0.6086 \\
\hline S28 & 10151812 & 0.3679 \\
\hline S29 & 10151780 & 0.3372 \\
\hline S30 & 10151811 & 0.2961 \\
\hline S31 & 17182236 & 0.2759 \\
\hline S32 & 17182289 & 0.2759 \\
\hline S33 & 17182232 & 0.2483 \\
\hline S34 & 17182218 & 0.1417 \\
\hline S35 & 17182237 & 0.3207 \\
\hline S36 & 17182169 & 0.1417 \\
\hline S37 & 17182174 & 0.3148 \\
\hline S38 & 17182143 & 0.2192 \\
\hline S39 & 17182148 & 0.1417 \\
\hline S40 & 17182208 & 0.2759 \\
\hline S41 & 17182212 & 0.1417 \\
\hline S42 & 17182275 & 0.1417 \\
\hline S43 & 16171974 & 0.2192 \\
\hline S44 & 16171951 & 0.1417 \\
\hline S45 & 16171903 & 0.2508 \\
\hline S46 & 16171923 & 0.2192 \\
\hline S47 & 16171976 & 0.1417 \\
\hline S48 & 16171982 & 0.2192 \\
\hline S49 & 16171916 & 0.2192 \\
\hline S50 & 16171947 & 0.2192 \\
\hline S51 & 16171870 & 0.1417 \\
\hline S52 & 10151681 & 0.2508 \\
\hline S53 & 10151670 & 0.1417 \\
\hline S54 & 10151578 & 0.2759 \\
\hline S55 & 10151700 & 0.2961 \\
\hline S56 & 10151584 & 0.3679 \\
\hline S57 & 10151647 & 0.254 \\
\hline S58 & 10151706 & 0.2196 \\
\hline S59 & 10151547 & 0.2802 \\
\hline S60 & 10151690 & 0.254 \\
\hline S61 & 10151585 & 0.2917 \\
\hline S62 & 10151660 & 0.2192 \\
\hline S63 & 10151628 & 0.177 \\
\hline
\end{tabular}

Sumber: Hasil Penelitian (2018)

\section{Desain Sistem}

A. Use Case Diagram 


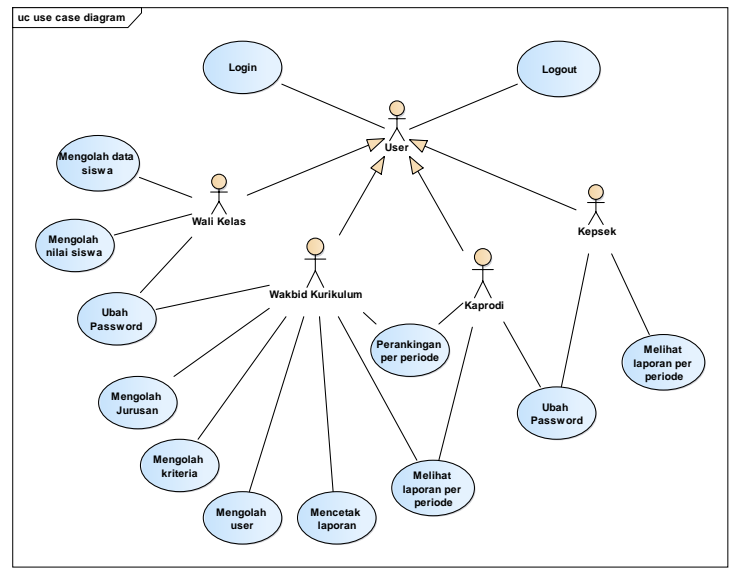

Gambar 2. Use Case Diagram Sisfo Pemilihan Siswa Berprestasi

Sumber : Hasil Penelitian (2018)

B. Activity Diagram

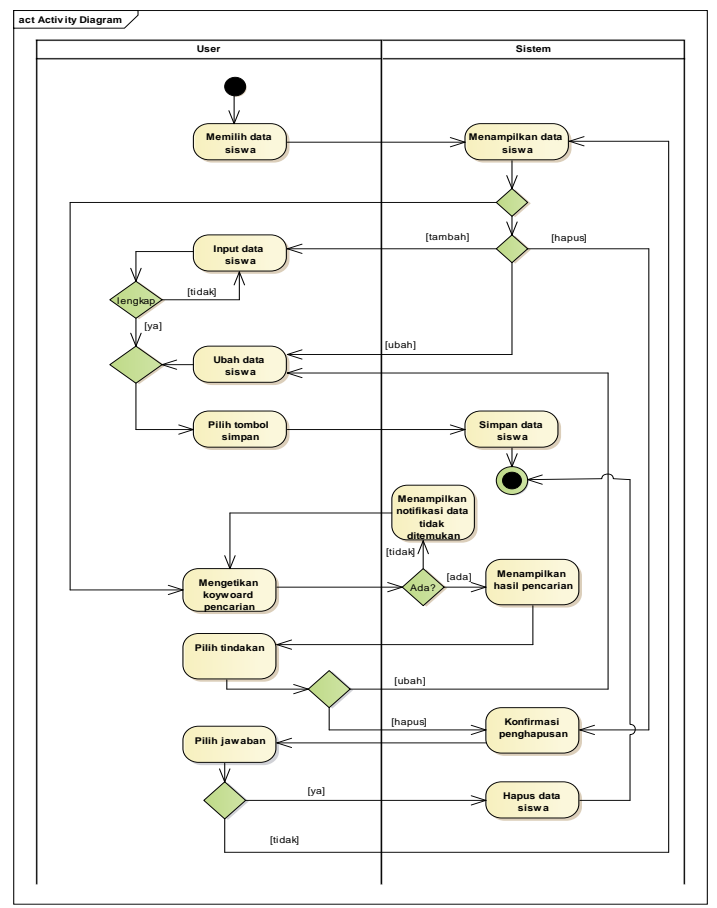

Gambar 3. Activity Diagram mengelola data siswa Sumber : Hasil Penelitian (2018)

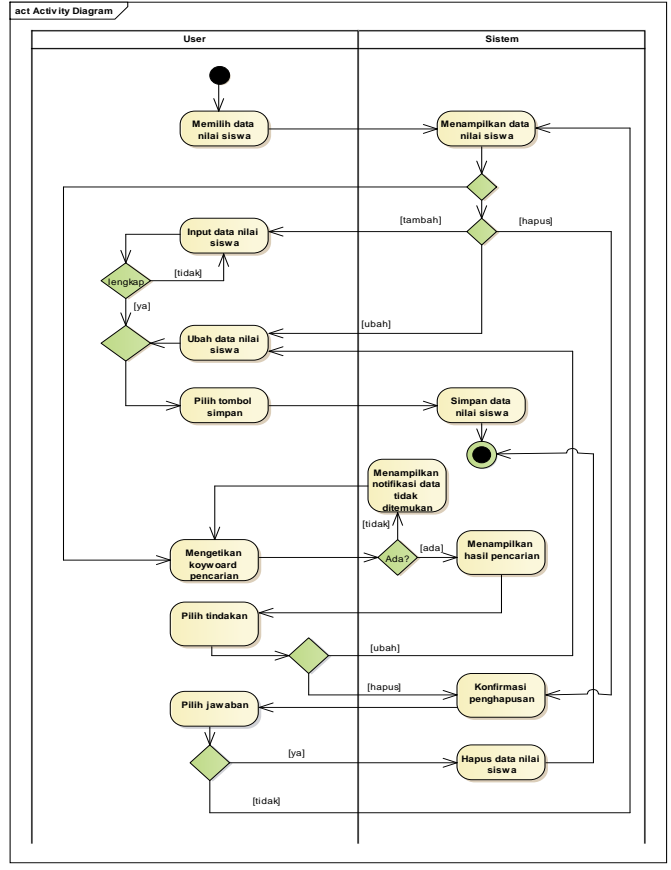

Gambar 4. Activity Diagram mengelola data nilai siswa

Sumber : Hasil Penelitian (2018)

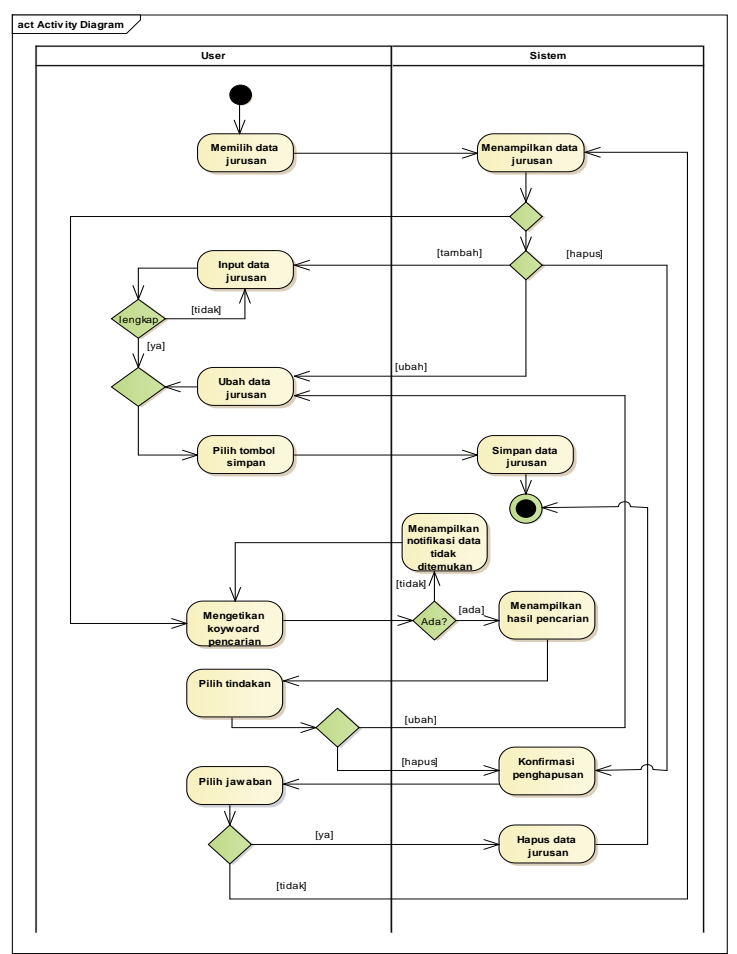

Gambar 5. Activity Diagram mengelola data jurusan

Sumber : Hasil Penelitian (2018) 


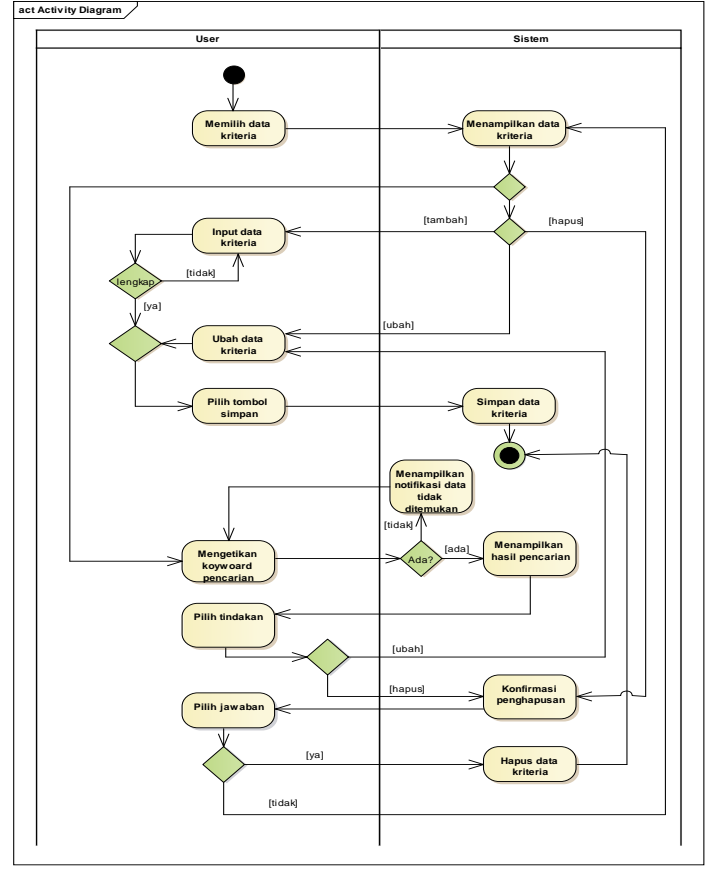

Gambar 6. Activity Diagram mengelola data kriteria

Sumber : Hasil Penelitian (2018)

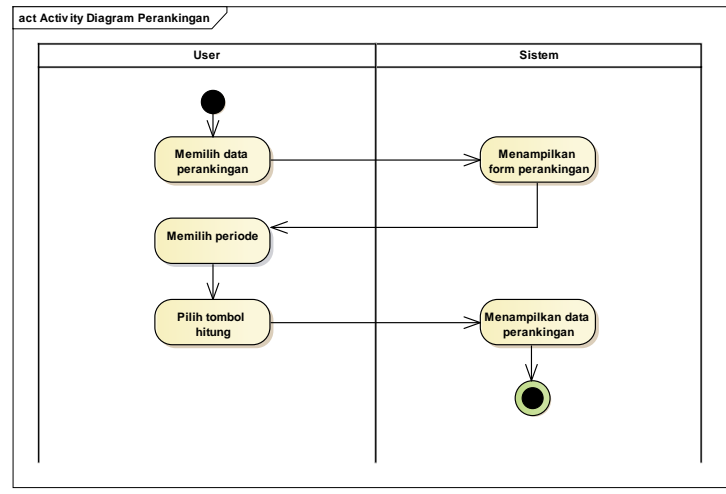

Gambar 7. Activity Diagram perankingan

Sumber : Hasil Penelitian (2018)

C. Component Diagram

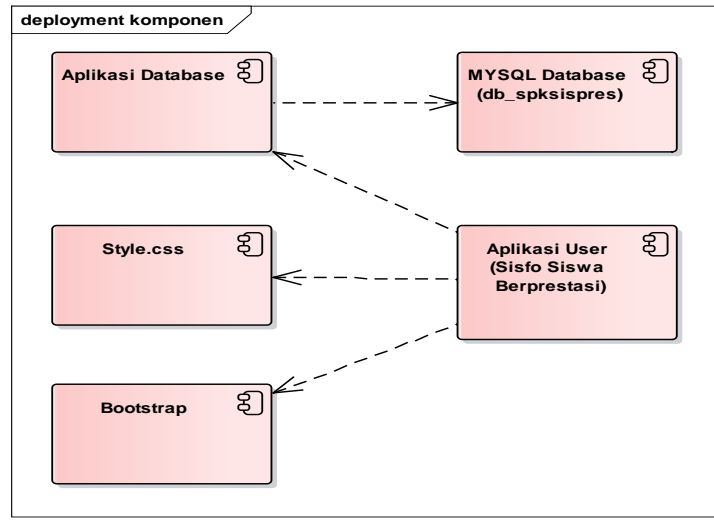

Gambar 8. Component diagram Sisfo Pemilihan Siswa Berprestasi

D. Sumber : Hasil Penelitian (2018)

\section{E. Deployment Diagram}

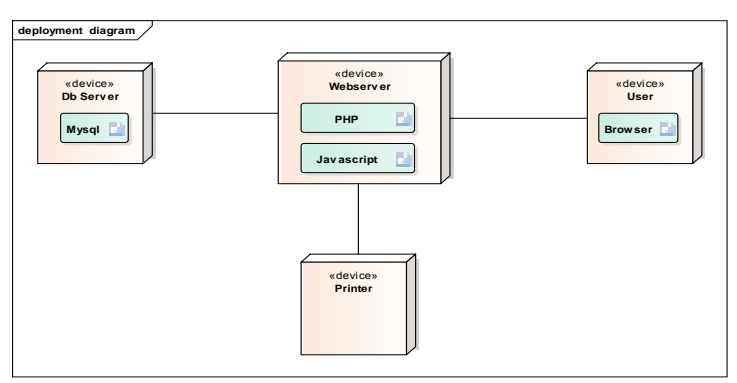

Gambar 9. Deployment diagram Sisfo Pemilihan Siswa Berprestasi

Sumber : Hasil Penelitian (2018)

\section{Desain Database}

Entity Relationship Diagram

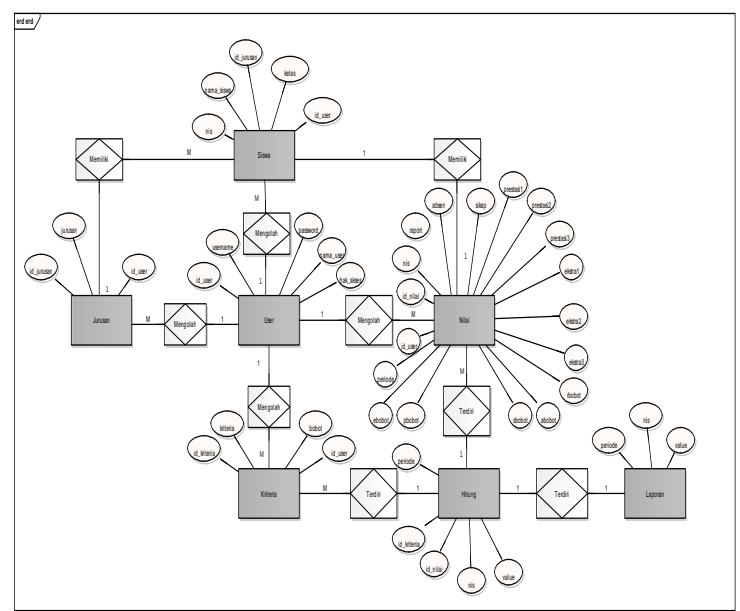


Gambar 10. Entity Relationship Diagram Sisfo Siswa Berprestasi

Sumber : Hasil Penelitian (2018)

\section{User Interface}

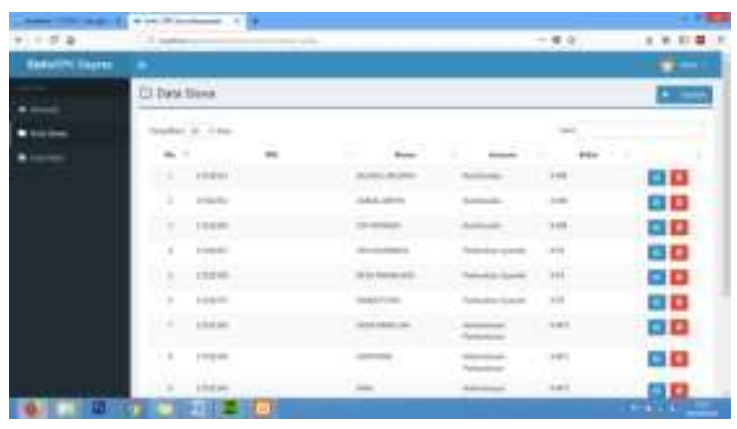

Gambar 11. Halaman Data siswa

Sumber : Hasil Penelitian (2018)

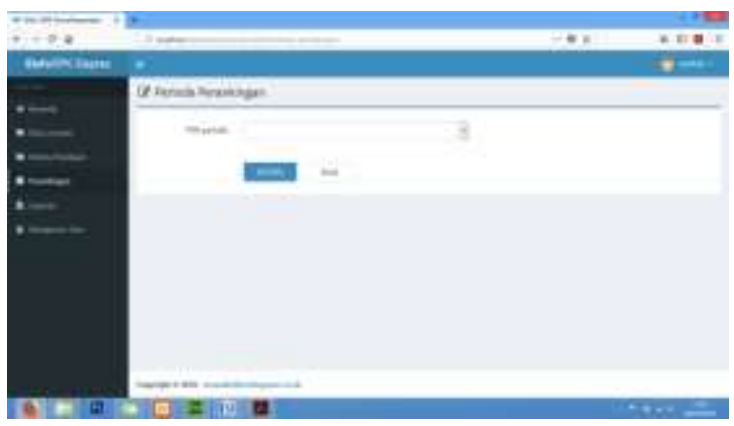

Gambar 12. Halaman Perankingan

Sumber : Hasil Penelitian (2018)

\section{KESIMPULAN}

Proses pemilihan siswa berprestasi pada SMK Yapia Parung belum tersistem berbasis program, dan masih membutuhkan banyak waktu dalam prosesnya dan pengolahan data siswa. Sehingga banyak sekali waktu dan tahap yang harus dilakukan dalam proses pemilihan siswa berprestasi. Untuk itu penulis mencoba membuat sistem informasi yang berbasi web desktop agar memudahkan pihak-pihak sekolah untuk mengakses pengolahan data nilai siswa berprestasi. Sehingga pihak sekolah dapat dengan mudah, cepat dan tidak membutuhkan waktu yang cukup lama lagi.

Dengan adanya sistem informasi pemilihan siswa berprestasi ini, secara tidak langsung SMK Yapia Parung dapat lebih mengurangi terjadi kesalahan atau ketidak akurat dalam pemilihan siswa berprestasi bagi pihak sekolah. Untuk mendukung keberhasilan dari implementasi sistem yang diusulkan serta pengembangan kearah yang akan datang, maka penulis menyarankan melakukan pemeliharaan perangkat keras (hardware) maupun perangkat lunak (software) sehingga sistem komputerisasi akan berjalan dengan baik, Melakukan back-up terhadap data secara periodik untuk menjaga hal-hal yang tidak diinginkan, Lakukan uprage program sesuai dengan kebutuhan pihak sekolah setiap periodenya, lebih mendetailkan lagi kriteria penilaian sikap siswa agar lebih akurat dalam proses pemilihan siswa berprestasi dan melakukan pelatihan atau training untuk pengguna aplikasi yang penulis buat.

\section{REFERENSI}

Amalia, H., \& . E. (2013). SISTEM PENUNJANG KEPUTUSAN KESEHATAN UNTUK HIPERTENSI MENGGUNAKAN ALGORITMA C4.5. Jurnal Pilar Nusa Mandiri, 9(1). Retrieved from

http://ejournal.nusamandiri.ac.id/ejurnal/index.php/ pilar/article/view/3/2

Hendini, A. (2016). PEMODELAN UML SISTEM INFORMASI MONITORING PENJUALAN DAN STOK BARANG (STUDI KASUS: DISTRO ZHEZHA PONTIANAK), (2). Retrieved from https://ejournal.bsi.ac.id/ejurnal/index.php/khatulist iwa/article/viewFile/1262/1027

Mardiana, T. (2018). SISTEM PENDUKUNG KEPUTUSAN PEMILIHAN MOBIL MURAH RAMAH LINGKUNGAN MENGGUNAKAN METODE TOPSIS. Jurnal Techno Nusa Mandiri, 15(1), 37-42. Retrieved from http://ejournal.nusamandiri.ac.id/ejurnal/index.php/t echno/article/view/804/pdf

Marlina, M., Yusnaeni, W., \& Indriyani, N. (2017). SISTEM PENDUKUNG KEPUTUSAN PEMILIHAN SISWA YANG BERHAK MENDAPATKAN BEASISWA DENGAN METODE TOPSIS. Jurnal Techno Nusa Mandiri, 14(2), 147-152. Retrieved from http://ejournal.nusamandiri.ac.id/ejurnal/index.php/t echno/article/view/525/370

Prabowo, H., \& . H. (2014). SISTEM INFORMASI PANDUAN TRAYEK ANGKUTAN UMUM BERBASIS MOBILE SMARTPHONE PADA DINAS PERHUBUNGAN JAKARTA. Jurnal Pilar Nusa Mandiri, 10(1), 56-71. Retrieved from http://ejournal.nusamandiri.ac.id/ejurnal/index.php/ pilar/article/view/76/72

Purwanto, H. (2017). SISTEM PENUNJANG KEPUTUSAN PEMILIHAN NOTEBOOK DENGAN MENGGUNAKAN METODE TOPSIS. Jurnal Ilmu Pengetahuan Dan Teknologi Komputer, 2(2), 55-59. Retrieved from http://ejournal.nusamandiri.ac.id/ejurnal/index.php/j 
itk/article/view/243/205

Puspitasari, D. (2016). SISTEM INFORMASI PERPUSTAKAAN SEKOLAH BERBASIS WEB. Jurnal Pilar Nusa Mandiri, XII(2). Retrieved from https://media.neliti.com/media/publications/227462 -sistem-informasi-perpustakaan-sekolah-be90754734.pdf

Rozaq, A., Lestari, K. F., Handayani, S., \& Banjarmasin, P. N. (2015). SISTEM INFORMASI PRODUK DAN DATA CALON JAMAAH HAJI DAN UMROH PADA PT. TRAVELLINDO LUSIYANA BANJARMASIN BERBASIS WEB, (1), 1-13. Retrieved from https://media.neliti.com/media/publications/159796
-ID-none.pdf

Rosa dan Shalahuddin. (2015). Rekayasa

Perangkat Lunak Terstruktur dan Berorientasi Objek. Bandung : Informatika.

Sasongko, A. (2017). SISTEM INFORMASI EDOSIR PESERTA PENSIUN ASURANSI (STUDI KASUS: PT ASABRI (PERSERO) CABANG PONTIANAK). Jurnal Techno Nusa Mandiri, 14(2), 97-102. Retrieved from http://ejournal.nusamandiri.ac.id/ejurnal/index.php/t echno/article/view/496/345 